\title{
The Changing Outlook in Agriculture.*
}

\author{
By Sir John Russeld, O.B.E., F.R.S.
}

$\mathrm{A}^{\mathrm{c}}$ GRICULTURE as an art was already far advanced when the first meeting of the British Association was held in 1831. It was then entirely empirical. Scientific work was, however, beginning, and round about 1840 three important events occurred: Liebig published his epochmaking essay on the application of chemistry to agriculture, Lawes began the famous Rothamsted experiments which almost at once led to the founding of the artificial fertiliser industry, and the Royal Agricultural Society started its beneficent work of fostering the application of science to practice. Economic conditions favoured the growth of the home agriculture, and from about 1850 to 1890 British agriculture flourished. Then within a few years it collapsed. The chain of transport arrangements with the United States and Canada was completed and farm produce came on to our markets at prices with which British agriculturists could not possibly compete.

The overseas systems were inferior to our own in production per acre, but the shortage of population had necessitated the development of laboursaving machinery, so that the production per man was greater, and this higher efficiency of output won the day. British farmers suffered greatly; many became bankrupt.

Gradually it was realised that the way out of the difficulty was to specialise, and this specialisation favoured the application of science to agriculture. From 1889 onwards, when the Board of Agriculture was founded, agricultural colleges began to grow up. The pioneers of those days-Middleton, Wood, Gilchrist, Somerville, Percival, F. B. Smith -to name only a few, had a strenuous uphill task. But the pioneers kept on with their struggle, and, inspired by the faith that was in them, they carried agricultural education through the length and breadth of the countryside.

Then came the system of county agricultural organisers. These now play so great a part in British agriculture that one is apt to forget that they began only about 1900 . The present widespread system was set up only in January 1919, when the Board of Agriculture, as it then was, circulated to the counties proposals for a comprehensive system of agricultural education, offering to pay 80 per cent of the organiser's salary and $66 \frac{2}{3}$ per cent of all other approved expenditure. With the organisers have grown up the farm institutes, and now there are springing up everywhere discussion societies where farmers meet to discuss technical and other matters of importance. At first no provision was made for research ; then it was realised that agricultural education could not be carried on without research. Research on any important scale became possible only after 1909 , when the Development Fund of $£ 2,000,000$ was set

* From the presidential address to Section M. (Agriculture) of the British Association, delivered in London on Sept. 25. up at the instance of Mr. Lloyd George for a variety of purposes, including research.

The Development Commissioners at the outset adopted the wise policy of allocating the several sections of agricultural science to existing institutions, making grants on an adequate basis, and so ensuring a widespread interest and, perhaps more important, a widespread net to capture young and capable research workers. Crop production (soil, plant nutrition, and plant pathology) was placed at Rothamsted, animal nutrition at Cambridge and the Rowett Institute, plant genetics at Cambridge and Aberystwyth, animal genetics at Edinburgh, agricultural botany at Cambridge, dairy research at Reading, fruit at Long Ashton and East Malling, economics and engineering at Oxford, horticulture and low temperature research at Cambridge, veterinary research at Cambridge and Weybridge, helminthology at the London School of Tropical Medicine, glasshouse horticulture at Cheshunt.

The scheme is worked through the Ministry of Agriculture, and it is one of the best instances of successful combination of Government supervision of finance with adequate freedom of action for the research worker. The general result of all these activities has been that farmers have learned to cheapen production, to seek profitable outlets for their industry, to use machinery and any other aids to production. Results soon appeared. When Hall, in the years 1910-12, made his classical pilgrimage of British farming, he records as his general impression that " the industry is at present sound and prosperous". This was less than twenty years after the deep depression of the early 'nineties.

Then came the War. For the British, for the overseas Empire and the United States, it was a time of feverish activity to raise more food to sell to the Allies. Prices were fixed in England, so that money never abounded in the countryside as it had done in Napoleonic times. In spite of the sadness of the War years, the farmers of Great Britain put up a wonderful fight to produce food. After the War came three years of high prices; in 1920 wheat averaged $80 \mathrm{~s}$. $10 \mathrm{~d}$. per quarter, the highest since 1818. Then just as suddenly there came the slump; by 1922 wheat was down to $47 \mathrm{~s}$. $10 \mathrm{~d}$.

The high prices had done farmers very little good, and in the end they lost all that they had gained. Many landowners proceeded to sell their estates. The high price of produce induced many to bid for the land, and the sitting tenant had either to outbid or be dispossessed. Frequently he had to pay more in interest on loans and mortgages than he had paid in rent, and in addition he has also to maintain the buildings, gates, and roads which formerly the estate had done. He is therefore in a far worse position than the farmer of 1821 in the slump after the high prices of the Napoleonic wars.

Much worse has come. When the first rush of cleaning up after the War was over, it was realised 
that the world's power of producing food had grown far in excess of its power of consuming food. The population had increased but the power of food production had increased much more. In consequence, prices of farm produce have fallen far more than costs of labour and of other commodities. British farmers have turned, as in the 1890 's, to live stock, raising lamb, young pigs, and milk so far as possible on grass with an increasing acreage of lucerne, thanks to the success of 'Thornton's inoculation method. Those who cannot produce grass cheaply and easily, but who have to depend on arable land, are in a sorry plight, and the difficulty is not confined to Great Britain; arable farmers in all civilised countries are deeply depressed.

This certainly is not the result that was expected ; on the contrary, experts had confidently predicted a food shortage. Sir William Crookes, in his presidential address to the British Association in 1898, forecast the probable world requirement of wheat for the next three decades, and showed that the sources and methods then available would continue to suffice only until 1931, when the world would begin to feel the pinch of hunger. Crookes's figures were remarkably accurate, and there can be nodoubt that, had science and practice stood still since 1898, we should now be facing the horrors of world starvation. But they have not stood still, and the present position of farm prices is a measure of their advancement.

Two new and closely linked factors have come into play since 1898 and are largely responsible for the present position: the widening of the scope of science in agriculture and the agricultural development of the British Empire and of South America. In the nineteenth century agriculture had been mainly a branch of chemistry ; its professors had been chemists, its laboratories chemical. Crookes suggested more chemistry as the way out of what he called the ' colossal dilemma' of world starvation ; he proposed the manufacture of more nitrogenous fertilisers from the air-a fantastic idea at the time, yet now our chief source of supply.

The new scientific developments came from the biological side, and the new practical developments from the engineering side. The first great biological triumphs were in plant breeding. Canada affords some of the best examples of the plant breeder's success in opening up new regions of the world for settlement. Up to the middle of the nineteenth century the Canadian wheats were suited only to the eastern provinces, Ontario and Quebec ; they were uncertain on the prairies. About 1842, David Fife, in Ontario, received for trial from a Glasgow friend several packets of wheat, which he sowed. Among the resulting plants was one that differed entirely from the rest, and also escaped damage from rust and frost, two destroyers of wheat in those times. How the seed got there, or whence it came, can never be known. It was a Galician variety. But the accident was a fortunate one for Canada, and did much to build up her wealth. The wheat plant was so good that Fife saved the seed and multiplied it, and in course of time it was widely taken up by farmers under the name of Red Fife.
It proved to be eminently suited to the prairies, and as soon as the railway was completed in 1886 it was taken there by the new settlers and became the basis of their prosperity.

Man-power was long the limiting factor in Canadian farming, and this problem of saving labour has been attacked with devastating thoroughness by engineers all the world over. The tractor and the new cultivating implements at and before seeding-time, and the combine at harvesting, have revolutionised wheat-growing by dispensing with enormous numbers of men and greatly increasing the area of land needed per man as an economic unit for wheat farming. Not long ago 160 acres was the economic unit for the family farm; now 320 acres is the lowest limit, and 640 acres is nearer the most profitable size.

Australia also has developed as the result of the activities of the plant breeder and the engineer; the problem here was the conquest of the drought. Farrer began by producing wheats more resistant to rust and drought than the older sorts, and his pupils, Sutton and others, have continued the work. Agriculturists showed the great value of superphosphate for all crops; they further improved the methods of cultivation, and now, as A. E. V. Richardson has shown, for each inch of rain falling during the season, the farmers of Victoria obtain one bushel of wheat, while forty years ago they obtained only half a bushel.

South Africa owes much of its advances to two other branches of biological science-veterinary science and parasitology. No part of the white man's habitation seems so suitable for insects, and especially parasites, as South Africa. So long as the white man occupied the country only thinly he could do it without difficulty, but trouble began as soon as he wished to increase his hold on the land and multiply his flocks and herds. The first to attack the problem seriously was Arnold Theiler. He founded the Veterinary Research Laboratories at Onderstepoort, of which not only South Africa but also the whole Empire is proud, and he trained up a body of veterinary research workers and officers who now, under the distinguished leadership of P. J. du Toit, are extending the good work.

We are still far from security; in the past twelve years foot-and-mouth disease has cost the British Government more than $5 \frac{1}{2}$ million pounds sterling, paid to the farmers of Great Britain as compensation for animals compulsorily slaughtered, while the farmers themselves have suffered vastly more. Veterinary research is now developing at Cambridge and elsewhere, and the relationships between nutrition and disease are studied at the Rowett Institute.

The engineer has perhaps been the greatest force in the development of New Zealand agriculture. The invention of refrigeration paved the way for the great dairy and lamb industries, which are now among the most remarkable and efficient agricultural industries in the world. The exports are rapidly rising. In 1929 that of butter was valued at $£ 13.2$ millions, of cheese $£ 7$ millions, frozen meat (mutton and lamb) $£ 9.9$ millions; in all, more than

No. 3242, VoL. 128] 
$£ 30$ millions by refrigeration transport, as against $£ 15$ millions of wool - a truly remarkable progress.

The development of the dairy industry, however, was not simply a matter of transport : it is a triumph for the bacteriologist. In Great Britain good work has been done at the Dairy Research Institute at Reading by Stenhouse Williams, Golding, and their colleagues. Australia has recentry made great progress with the dairy industry, and is now going into the question of lamb. Canada has a highly developed dairy industry.

Another result of improved storage during transport has been a great development of Empire fruit growing. Apples and oranges were formerly obtainable in England only in winter; they are now obtainable in spring and summer, thanks to the marked developments in Tasmania, the Murray region in Australia, and South Africa. Plums, peaches, grapes come in abundance from South Africa, bananas from Jamaica; not only are the total imports of fruit increasing, but also the proportion from the Empire increases ; it had averaged 24 per cent for the five years 1925-29, and rose to 33 per cent in 1930 ; home growers supplied 26 per cent-usually their share is nearer 30 per cent. The Empire still, however, supplies less than one orange out of every four that we eat, only 39 per cent of our bananas, 16 per cent of our grape fruit, and 10 per cent of our pineapples; there are therefore considerable possibilities of further development. Demand is increasing; in 1930 the consumption of fruit per head of population in Great Britain was nearly $83 \mathrm{lb}$., as against $70 \mathrm{lb}$. in 1924 . Other countries are improving their production and transport. In Great Britain, Barker, Wallace, and their colleagues at Long Ashton, and Hatton at East Malling, have greatly strengthened the fruit growers' position, and for fruit the outlook is, as for other commodities, a power of production growing greater than the power of consumption. Another important factor in the fruit industry has been the development of canning, which affords a satisfactory way of dealing with excess produce.

Engineering science has further intensified agricultural production by developments in irrigation. The greatest triumphs of irrigation in our time have been in India. The cultivable area of India has been enormously increased, and land provided for millions of peasants who would otherwise have had none.

Irrigation schemes worked by white men are so costly that only valuable products can be raised. In all cases irrigation has greatly increased the output from the land and greatly increased the supplies for the world market. If time permitted, it would be possible to go through the whole list of products of the earth and show how modern science has increased output far beyond human needs, with a resulting fall in demand and lowered prices. One could dilate on the achievements of the Dutch in Java in producing their new sugar-cane, which quadrupled the output and so lowered the price of sugar that the West Indies are in terrible distress, the sugar-beet industry of Great Britain is threatened, and all Europe would be in trouble but that they artificially keep out the new sugar. Or again, one could speak of the achievements in rubber growing, of the change over from wild rubber to plantation rubber, of the extraordinary improvements in technique, which have in the past thirty years so enormously increased the output that even the most extensive new demands of modern civilisation-rubber tyres, rubber floors-have failed to keep pace with supplies, so that the price, which in 1910 was $12 s .6 d$. per lb., is now reduced to $3 d$., and may fall still lower, causing great distress to the rubber growers.

Modern science, in short, has been so successful in increasing man's power over Nature that it has brought us harvests far more bountiful than we know what to do with. Yet, although we may think in our pride that we have achieved a wonderful control over Nature, our control is really very limited, our tenure uncertain, and our margin of safety very exiguous. How long mankind will have the wit to go on developing more powers we do not know. It is quite certain that any slackening of control or failure to utilise scientific discovery by any one group of cultivators would speedily eliminate them through pressure of more enlightened and therefore more successful competitors. It is, however, not so much human competition as the opposing natural agencies that must continuously be watched. The weather can still defeat our best laid farming plans. Over large parts of our Empire there is a continuous struggle for possession between insects and men, and the margin of victory, even when we get it, is never very great.

There are also new troubles as yet only dimly seen that may easily cause great difficulty in future. The remarkable development of rapid transport has carried all over the world not only the blessings but also the evils of this earth. Pests and diseases of animals, and particularly of plants, have only to appear in one corner of the globe to spread elsewhere with great rapidity despite all regulations to the contrary, often causing enormous losses. Among the most serious troubles of modern times are the virus diseases of plants. These diseases are apparently not caused by any recognisable living organism, nor are they simple physiological disturbances; they cannot yet be attributed to any definite causal agent. They spread rapidly, being frequently carried by small insects, sometimes by mere contact, and they cannot be cured-one can only stand by and see the plants perish.

All kinds of crops are affected: sugar-cane, tobacco, cotton, sugar-beet, groundnuts, bananas, potatoes, maize, timber trees (for example, sandal), large and small fruits (for example, peach and raspberry), and most greenhouse and horticultural plants. Moreover, it is not so much sickly plants as healthy ones that suffer In Gambia the Rosetta disease cut down the crop of groundnuts to about one-third of the normal yield. In the United States in 1926 two virus diseases reduced the crop of potatoes by no less than 16 million bushels. In Great Britain the total loss cannot be estimated, but the figures recorded for various attacks vary from 35 to 75 per cent loss of crop. Worse still is the 
deterioration of stocks : stocks apparently healthy and vigorous may become worthless in two to four years. Cotton growers are becoming seriously perturbed. In the Gezira last year the losses were considerable, although until recently the leaf-curl disease was unknown there. Sugar-beet in the south-western region of the United States is so seriously imperilled by the curly-top disease that the Government has set aside 300,000 dollars for its investigation. In England special grants are made to Rothamsted, Cheshunt, Bangor, and other institutions to study these diseases. Tobacco is now being badly attacked, also tomatoes and potatoes; the latest sufferers are the narcissi and daffodils in our own gardens ; these cease to flower and shortly perish. Virus diseases are quite recent as serious plagues; if they are old, they have hitherto been unimportant or unnoticed. Clearly, Pandora's box is not yet empty.

The United States stands easily first in elaboration of agricultural research, organised not only by the Government but also by private endowment. Both in England and in the United States, men who have made fortunes in the city have spent their money in developing agriculture or agricultural science. The America patron has spent his money on a college or research station, setting up a laboratory or some other new building, or endowing fellowships, so that a succession of vigorous young people could develop the subject, adding also greatly to their own value as workers for agricultural progress. So the gift has fructified and enriched the community in ever-widening circles. The British patron, on the other hand, has usually spent his money on his own estate, making his own experiments in farming. Some have rendered service by carrying pedigree live stock over periods of depression when the commercial farmer might perforce have had to let them go. But many have simply experimented on no very definite basis and with none of the continuity essential to the success of agricultural investigation. While, no doubt, getting much amusement out of it themselves, they have not achieved results commensurate with the time and money expended.

Without disputing the inalienable right of the Englishman to spend his money in any way he may think fit, we can still commend to the English patron the wonderful possibilities of the endowment of agricultural research. To say nothing of Lawes and Rothamsted, think what the world has gained through John Quiller Rowett's gift in 1920 of land near Aberdeen, and of $£ 10,000$ to erect buildings, thus founding the Rowett Institute. Scotland has recently had a further benefaction in the Macaulay Soil Institute set up to study the peat soils of Scotland and to help the farmers there so long as any men farm in Scotland. We remember with gratitude, and we know that our children will do so, the names of Molteno, William Dunn, Thomas Harper Adams, Charles Seale-Hayne, John Innes for their foundations in England ; Peter Waite and John Melrose for the Waite Institute in Australia, William Macdonald for the Macdonald College in Canada, Thomas Cawthron for the Cawthron
Institute in New Zealand. To-day the need is not so much for new institutions as for the strengthening of some of those already in existence.

Within the Empire all agricultural experts are now in touch with the central clearing houses in Great Britain, the Imperial agricultural bureaux, the function of which is to search the world for information likely to be useful and then pass it on to the persons likely to want it. The system is working well.

World organisation of scientific investigation is proceeding rapidly. Of the three factors involved in the agricultural situation, production, market. ing, and the scientific advisory and technical system, the last is by far the best organised. Much has recently been done, however, in developing better and more efficient marketing by the Empire Marketing Board and the Ministry of Agriculture.

Our greatest need, however, is a better organisation of agricultural production. A beginning has been made by the overseas farmers ; the necessity for sending all produce through one or two ports has compelled them to work through large organisations for grading, transporting, and selling the produce, with skilled representatives in Great Britain. Dealing in hundreds or thousands of tons, they reduce all costs and all wastage to a minimum. Gradually the British farmer is organising. But greater organisation is highly desirable. At present British farmers, Empire farmers, and farmers from all over the world indulge in deadly competition in the British market. In the end they obtain wholly inadequate prices. But the com. munity as a whole does not gain because they lose.

Thanks to the inquiries made by the Ministry of Agriculture and the Empire Marketing Board, the food requirements of Great Britain are fairly well known. Our next great step forward will be to organise production on a contract basis so as to satisfy these requirements with a reasonable margin of safety, but without the terrible waste involved in those large excesses which injure the grower without benefiting the consumer.

Something of the sort is essential if farming is to survive as an occupation for the best of our people. Organised production and the development of the contract system which has done so much for the milk producers, would permit of a renewal and development of country life to the fullest extent now made possible by scientific and technical advances. By common consent many of the ills of to-day arise from the fact that for nearly a century the industrial side of our national life has been fostered at the expense of the rural side, producing an over-industrialised town population peculiarly susceptible to world economic disturbances, and now largely without employment or prospect of employment. The rural population, on the other hand, is far less sensitive to economic disturbances; the low rate of unemployment in the countryside shows the greater independence and resilience of the conditions of country life, and points clearly to the fact that improvements in our rural life would benefit not only the countryman but also the whole community. 